ZatącZnils

DOI 10.21697/zk.2020.7.28

\title{
OŻYWCZOŚĆ SEMIOTYCZNEJ OPTYKI. GŁOŚNO MYŚLĄC NAD KATEGORIA ŻYWOTNOŚCI (I) TEKSTU
}

KatARZYNA MACHTYL

Wydział Antropologii i Kulturoznawstwa UAM
Faculty of Anthropology and Cultural Studies,
Adam Mickiewicz University in Poznań
machtylk@amu.edu.pl
ORCID:0000-0002-3959-5633

Życie tekstu, życie apokryfu, życie symbolu. Życie semiotyczne i semantyczne. Życie pełnią życia i burzliwe. Wszystkie te określenia napotykamy, przedzierając się przez gęsty, żywy tekst książki Małgorzaty Jankowskiej Żywotność [nomen omen - K.M.] kanonu. Semiotyka współczesnej apokryficzności $i^{1}$. Przy pełnej świadomości, że nierzadko tekst i życie wchodzą tu ze sobą w związki jedynie na drodze zwyczaju językowego, nie mogę oprzeć się pokusie, by pomyśleć o ich relacjach przekraczających system języka. Czy będą to zatem związki rzeczywiste, a więc realizujące się w przestrzeni pozaznakowej, czy też ograniczające się do metafory - zależeć będzie od obranej optyki. Gdy pomyśleć o życiu rozumianym najdosłowniej i spróbować odnieść je do sfery znaków, rozważania te przenieść by było trzeba na grunt biosemiotyki, nie jest to jednak cel mojego namysłu, którym dzielę się w tym tekście. Co innego w sytuacji, gdy życie pojmiemy nieco tylko mniej dosłownie i tym samym nieco tylko bardziej metaforycznie, co chciałabym tu zaproponować.

Wspomniana książka, na marginesie której spisuję swoje głośne myślenie, stanowi znakomity przykład złączenia trzech punktów widzenia: semiotycznego, studiów nad pamięcią kulturową i kulturoznawczego. Spojrzenia te przecinają się w figurze apokryfu - głównego obszaru badań monografii,

1 M. Jankowska, Żywotność kanonu. Semiotyka współczesnej apokryficzności, Poznań 2019. Wszystkie odwołania do tej pozycji zamieszczam w tekście głównym, podając w nawiasie numer strony. 
który, w konsekwencji, jest w niej określany jako m.in. „efekt twórczego przekładu”, „narzędzie autokomunikacji kultury”, „instrument metarefleksji kulturowej”, „medium pamięci kulturowej” czy wreszcie „narzędzie (re)witalizacji symbolu" (s. 152-160). Zaryzykuję stwierdzenie, że nie byłoby to możliwe, gdyby nie, po pierwsze, przyjęcie perspektywy uwzględniającej wspomniane trzy zaplecza teoretyczne, ale również - po drugie - bez wzięcia pod uwagę perspektywy szeroko rozumianego życia. Jak niejednokrotnie w Żywotności kanonu autorka zaznacza, określenie „życie tekstu” czerpie od Jurija Łotmana. Taki też jest punkt wyjścia mojej, zainspirowanej Żywotnością kanonu, refleksji nad relacją tekst - życie, co implikuje z jednej strony postrzeganie obu tych realności ${ }^{2}$ jako odrębnych, $z$ drugiej zaś kieruje myśl ku życiu tekstu.

„Semiosfera jest »niedomknięta $i$ jako taka nie może być w pełni oddana w »zamykającym ją" oglądzie" (s. 174) - pisze autorka i w zasadzie kumuluje w tym stwierdzeniu wszelkie istotne dla mnie intuicje i konstatacje Łotmana, jak i zapowiada kierunek refleksji, jaką zamierzam tu podjaćc. Gdy mowa o „późnym” Łotmanie, a więc tym okresie jego pracy, który obejmuje publikację trzech książek, tzw. późnej trylogii: Uniwersum umysłu, Kultury i eksplozji oraz Nieprzewidywalnych mechanizmów kultury, napisanych pod koniec XX wieku, za słowa-klucze uznać można dynamikę, ruch, translację, przekształcenie czy właśnie tytułowe eksplozję i nieprzewidywalnośćs. Jeśli zaś pokusić się o wspólny dla nich mianownik, można przyjąć, że może być nim właśnie życie. „Żywy” tekst bowiem to taki, który pozostaje w ruchu, poddaje się translacji i przekodowaniu, a dzieje się to dzięki życiodajnej dynamice i eksplozji. Tak rozumiane życie i żywotność tekstu będą jedną z dwóch osi, na których opieram proponowane tu rozważania, drugą oś stanowi „niedomkniętość” semiosfery, pozytywnie waloryzowana, w przeciwieństwie do jej „zamkniętości”. Bycie niedomkniętą bowiem stanowi

2 Jest oczywiście kwestią dyskusyjną, czy tekst będziemy traktować jako realność właśnie czy jako konstrukt. Pozostawmy jednak te rozważania na inną okazję. W niniejszym szkicu kwestię tę rozstrzygać będą sami przywoływani autorzy.

3 Szerzej piszę na ten temat m.in. w tekście: Znaki w ciagłym ruchu. Od optyki podmiotu po perspektywę kulturowa, [w:] Kultury w ruchu: migracje, transfery, epistemologie, red. R. Koschany, M. Michałowska, J. Ostrowska, A. Skórzyńska, Poznań 2019, s. 121-134. 
warunek pozostawania przy życiu. „Niedomknięta” niech stanowi tu szersze semantycznie określenie, pod którym rozumiem także węższe: niedookreślenie, niezrozumienie i nieprzejrzystość, przy czym to drugie domaga się złagodzenia i ujęcia w formule: „nie do końca zrozumienie”.

Wszelka kultura stale poddawana jest bombardowaniu ze strony spadających na nią - jak deszcz meteorytów - przypadkowych pojedynczych tekstów. Chodzi tu nie o teksty włączone do określonej spójnej tradycji, wywierające wpływ na daną kulturę, lecz właśnie o oddzielne nieocze kiwane ingerencje. [...] Gdyby teksty nie posiadały swej pamięci i nie mogły stwarzać wokół siebie określonej aury semantycznej, wszystkie te ingerencje pozostałyby muzealnymi rarytasami, znajdującymi się poza podstawowym procesem kulturowym. W rzeczywistości okazują się one ważnymi czynnikami, prowokującymi dalszy rozwój kultury. Wiąże się to z tym, że tekst - podobnie jak zi a r no, które zawiera program przyszłego rozwoju - nie jest zastygłą i zawsze równą sobie faktycznością. Wewnętrzna niedookreślon ość jego struktury wytwarza pod wpływem kontaktów $\mathrm{z}$ nowymi kontekstami rezerwę dla jego dynamiki ${ }^{4}$.

W przywołanym fragmencie Uniwersum umysłu Łotmana wyróżniłam istotne w świetle przedstawionych tu rozważań określenia. Zacznijmy od ziarna - analogii do natury nie trzeba szczególnie tłumaczyć, odkąd wiemy, że termin i pojęcie semiosfery wzorował Łotman na biosferze Władimira Wiernadskiego. Stąd też u autora Kultury i eksplozji porównania do błony, membrany, komórki etc. Tu także szukać należy teoretycznego tła dla jego konstatacji, że oto „[...] semiosfera współczesnego świata, która stale się rozszerzając w przestrzeni w ciągu wieków, przybrała obecnie globalny charakter, zawiera w sobie i sygnały sputników, i wiersze poetów, i krzyki zwierząt. Wzajemny związek tych elementów przestrzeni semiotycznej nie jest metaforą, lecz realnością"5. Porównanie tekstu do ziarna, mającego pewną potencjalność, jednak „gotowego” na zmianę w spotkaniu z innym: tekstem bądź kontekstem, opisuje życie każdego tekstu jako „zaprogramowanego" wprawdzie u swych początków, ale jednocześnie elastycznego

${ }^{4}$ J. Łotman, Uniwersum umysłu. Semiotyczna teoria kultury, tłum. i wstęp, B. Żyłko, Gdańsk 2008, s. 78 (podkr. K.M.).

${ }^{5}$ Idem, O semiosferze, [w:] idem, Kultura, historia, literatura, tłum., wyb. i wstęp B. Żyłko, Gdańsk 2017, s. 106. 
i wrażliwego na otoczenie. Wedle Michaiła Bachtina tekst zawiera w sobie znaczenia ukryte i jawne, które się w nim otwierają, co więcej - zawsze w dyspozycji pozostają jeszcze sensy zapomniane. „Skumulowane ślady znaczeń"6 objawiają się niejako w każdym pojedynczym zastosowaniu języka, w rozmaitych kontekstach. „Tekst to nie rzecz”, lecz „pierwotna realność" - cytuje Bachtina Lech Witkowski. Teksty, podobnie jak ludzie, pozostają ze sobą w dialogu, bywa że i niezwieńczonym; komunikują się ze sobą, co jest z kolei gwarantem ich życia.

Aby więc tekst żył, mówiąc po Bachtinowsku - kontynuuje Witkowski nie może być traktowany jako zamknięty w sztywnych granicach, jego nośność wyraża się obecnością treści pogranicznych. [...] Tekst nie może ani nadawać, ani być odbierany w zawężeniu do własnej, fizycznie istniejącej, autonomicznej warstwy znakowej; wszystko, co w nim ży je, nosi charakter intertekstualności otwierającej znaczenia przyległe - choć pozornie poza tekstem, bo milczące bądź wręcz ukryte, jak i znaczenia lgnące, to jest te, które w skracaniu dystansu i w operowaniu na pograniczu tekstu poszukują szans i tworzą warunki dla chłonności myślowej ${ }^{8}$.

Tekst, który żyje, to więc ten - w świetle zrekonstruowanej przez Lecha Witkowskiego myśli Bachtina - który nie jest zamknięty, a otwarty na swoje pogranicza. Realność tekstu zatem i pozytywnie waloryzowana jego niedookreśloność są - jednymi z wielu, dodajmy - miejscami, w których myśl Bachtina i Łotmana zdaje się przecinać. Podobnie rzecz ma się z potencjalnością: „istnienie znaczeń w kulturze jest zawsze pograniczne w tym sensie, że jest na granicy bycia i niebycia, obecności i nieobecności tego, do czego owe ślady znaczeń odsyłają" ". To także pozwala nam rozumieć kulturę jako pulę (pole) sensów ${ }^{10}$.

W przywołanych wyżej słowach Łotmana wyróżniłam także „nieoczekiwane” i „niedookreśloność”. Prowadzi nas to z kolei do zapowiedzianego

${ }^{6}$ L. Witkowski, Uniwersalizm pogranicza. O semiotyce kultury Michaiła Bachtina w kontekście edukacji, Toruń 2000, s. 125.

7 M. Bachtin, Estetyka twórczości słownej, cyt. za: L. Witkowski, op. cit., s. 100.

8 L. Witkowski, op. cit., s. 125 (kursywa oryginalna, podkr. K.M.).

9 Ibidem.

10 Ibidem, s. 111. 
niezrozumienia, a mówiąc dokładniej - do akceptacji częściowego niezrozumienia:

[...] nie tylko zrozumienie - pisze Łotman - ale i niezrozumienie jest koniecznym i pożytecznym warunkiem komunikacji. Tekst absolutnie zrozumiały jest zarazem tekstem absolutnie bezużytecznym. Absolutnie zrozumiały i rozumiejący interlokutor byłby wygodny, ale niepotrzebny, gdyż [...] obcowanie z nim nie zwiększyłoby mojej wiedzy, podobnie jak przekładanie portmonetki z jednej kieszeni do drugiej nie wpłynie na zwiększenie znajdującej się w niej sumy pieniędzy $y^{11}$.

Przypomniawszy stwierdzenie Bachtina o łańcuchu wypowiedzi i niezwieńczonym dialogu, nietrudno zauważyć paralelność myśli obu autorów. „Wynik końcowy wysiłku rozumienia nie może być z góry przesądzony czytamy w Uniwersalizmie pogranicza - [...] rozumienie to walka o wspólną korzyść pogłębienia własnego widzenia danego przedmiotu (utworu, tekstu, świata) w procesie interakcji"12. Owo niezrozumienie, powtórzmy - waloryzowane zdecydowanie pozytywnie, będące gwarancją podtrzymania dialogu, a co za tym idzie: utrzymania tekstu (jakkolwiek szeroko rozumianego) przy życiu - jest również znakomicie problematyzowane na gruncie hermeneutyki. W pracy Oblicza hermeneutyki Paweł Dybel zaznacza, że „u podstaw hermeneutyki tkwi proste pytanie: jak mam zrozumieć, co mówi do mnie inny?", i zwraca uwagę na nierozdzielność zrozumienia i porozumienia ${ }^{13}$. Dybel ponadto zauważa, że najbardziej pożądaną postawą jest zgoda na „dramat rozumienia” oraz nieprzybieranie postawy otwartej. Jak należy te słowa rozumieć? Właśnie w świetle przywołanych wyżej ustaleń Łotmanowskich: „[...] tylko wówczas - przekonuje z całą stanowczością Dybel - gdy zrozumienie czegoś zaczyna sprawiać nam jakąś wielką trudność, otwiera się przed nami możliwość »wprawienia w ruch « naszego rozumienia. Zaczynamy myśleć, wykraczając poza określający nas do tej pory horyzont samorozumienia" 14 . Krytyka całkowicie otwartej postawy, zdawać by się mogło - bardzo kontrowersyjna, okazuje się pozostawać

${ }^{11}$ J. Łotman, Uniwersum umystu..., op. cit., s. 154.

12 L. Witkowski, op. cit., s. 146-147.

13 P. Dybel, Oblicza hermeneutyki, Kraków [cop. 2012], s. 8.

14 Ibidem, s. 14. 
w zbieżności z myślą Łotmana. Tylko wówczas, gdy zdobędziemy się na odwagę „wprawienia w ruch” (sic!) własnego rozumienia, wypadnięcia z torów, otworzy się perspektywa dialogu i życia. Zgoda na niezrozumienie, akceptacja potencjalności konfliktu, „szmerów” komunikacyjnych i możliwości niezrozumienia, otwiera drogę życia.

Niech będzie mi wolno - czuję się usprawiedliwiona konwencją glosy przenieść proponowane tu refleksje na całkiem inną (całkiem - bo również nie semiotyczną, jednak nadal hermeneutyczną) płaszczyznę, mianowicie przywołać myśl współczesnego hermeneuty, Gianniego Vattimo, a przede wszystkim jego koncepcję przejrzystości. Zdawać by się mogło, że przejrzystość ma konotacje wyłącznie pozytywne, zatem i włoski hermeneuta winien tak ją postrzegać. Nic bardziej mylnego. Otóż podobnie jak Dybel zwrócił uwagę, że to niezrozumienie jest raczej pożądanym stanem, nie zaś pełnia zrozumienia, tak Vattimo zauważa, że ideał przejrzystości nie powinien być celem dążenia, gdyż to „»chaos« stanowi naszą nadzieję na emancypację"15. Warto przytoczyć słowa autora Końca nowoczesności, w których charakteryzuje rzeczywistość jako „rezultat krzyżowania się, »kontaminacji« (w łacińskim sensie tego słowa) wielości obrazów, interpretacji, rekonstrukcji, które, niekoordynowane przez jakiekolwiek »centrum«, rozpowszechniają konkurujące ze sobą media. [...] Ideał emancypacji oparty jest na oscylacji, pluralizmie i całkowitej erozji »zasady rzeczywistości«"16. Rzecz jasna, poczynić tu należy pewne zastrzeżenia: Vattimo, po pierwsze, występuje z pozycji hermeneuty, nie semiotyka kultury, po drugie zaś swoje rozpoznania lokuje w szerszym planie „końca nowoczesności”, który zestawić można ze „słabą myślą", a także końcem zachodniej metafizyki - i to stąd mowa w przywołanym fragmencie o „całkowitej erozji zasady rzeczywistości”. Trudno jednak nie dostrzec pewnych wspólnych wątków w podejściu jego i tym reprezentowanym zarówno przez Łotmana, jak i Bachtina. U wszystkich tych autorów można wszak zauważyć - nie zawsze bezpośrednie, ale jednak - nawiązania do myśli hermeneutycznej. Vattimo ponadto, pisząc o braku koordynacji przez centrum i krzyżowaniu się wielu interpretacji, wpisuje się, zapewne całkiem nieświadomie, $\mathrm{w}$ dyskurs proponowany przez rosyjskiego semiotyka

15 G. Vattimo, Społeczeństwo przejrzyste, tłum. M. Kamińska, Wrocław [cop. 2006], s. 18.

16 Ibidem, s. 21. 
i, jak chciałabym wierzyć, nie są to wyłącznie podobieństwa na poziomie leksykalnym. Zobaczmy jednak, jak Vattimo problematyzuje społeczeństwo przejrzyste - był to wszak główny powód uwzględnienia jego głosu w niniejszych rozważaniach: „społeczeństwo nieograniczonej komunikacji jest społeczeństwem przejrzystym, które potrafi radykalnie redukować przyczyny konfliktów, usuwając przeszkody i zniekształcenia”"17, i kontynuuje: „ideał samoprzejrzystości społeczeństwa jest [...] przekonujący jedynie z punktu widzenia podmiotu zajmującego centralną pozycję"18. Jako alternatywę proponuje „hermeneutyczną” logikę, zgodnie z którą prawda rozumiana jest jako „ciągłość” i „dialog między tekstami”19. Skoro tak, w kontrze do Habermasowskiego ideału działania komunikacyjnego i opartej na nim etyce komunikacji, Vattimo proponuje etykę interpretacji, gdyż normatywny ideał nieograniczonej komunikacji - podobnie jak Dybel ideał pełnego zrozumienia innego, a Łotman: tekstu - postrzega negatywnie. Pojmując doświadczenie prawdy jako artykulacje i interpretacje zachodzące wewnątrz różnorakich uniwersów kulturowych, konstatuje, że jedyną możliwą do przyjęcia teorią prawdy jest teoria prawdy jako interpretacji (nie korespondencji), stąd też właśnie jego propozycja etyki interpretacji w miejsce etyki komunikacji ${ }^{20}$.

Mając to wszystko na uwadze, przejdźmy jeszcze - ostatni już raz, zanim na powrót przeniesiemy nasze rozważania w obszar refleksji stricte semiotycznej - do kolejnego tekstu, któremu chciałabym oddać głos, mianowicie do szkicu Humanistyka po dekonstrukcji Michała Pawła Markowskiego. Głos ten nie powinien być odebrany jako „mówienie obok siebie”, a raczej jako przejaw polifonii, gdyż zaproponowane w nim rozstrzygnięcia dialogują, po pierwsze, z rozważaniami zawartymi w Żywotności kanonu - autorka niejednokrotnie odwołuje się do Paula Ricouera czy Clifforda Geertza (zob. chociażby s. 53-71 czy 142-146), uruchamiając kategorię interpretacji, a po drugie - i przede wszystkim - Markowski eksponuje tu kategorię życia. By nie obciążać nadmiernie mojej wypowiedzi zbyt drobiazgową rekonstrukcją wyłożonej w artykule Markowskiego argumentacji, przedstawmy jedynie najważniejsze dla nas konstatacje. Autor Polityki wrażliwości stawia tezę,

\footnotetext{
17 Ibidem, s. 33.

18 Ibidem, s. 35.

19 Ibidem, s. 38-39.

20 Ibidem, s. 119-125.
} 
że humanistyka po dekonstrukcji nie tylko nie jest w kryzysie, a wręcz przeciwnie: dekonstrukcja tchnęła życie w „nauki o duchu” ${ }^{21}$. Rozważania Markowskiego wpisują się w całkiem powszechny ogląd, wedle którego najpierw strukturalizm, a w zasadzie i wcześniejszy formalizm rosyjski, a później poststrukturalizm i dekonstrukcja doprowadziły do rozłamu między tekstem a rzeczywistością, tekstem a ontologią aktualności, tekstem a życiem wreszcie. Odnosząc się oczywiście do Derridy i sposobu, w jaki jego myśl została odebrana, zauważa, że poststrukturalizm i dekonstrukcję zaczęto oskarżać o tekstualizację rzeczywistości, czego skutkiem jest całkowita nieprzystawalność tekstu i życia. Tymczasem, jak pisze Markowski, „dekonstrukcja [...] stara się opisać nieusuwalną historyczność naszej egzystencji" 22, a obranie perspektywy historycznej i uwzględnienie czasowości ludzkiego życia i doświadczenia niejako wymuszają "heremeneutyczne” spojrzenie, a przede wszystkim wracają tekst życiu. Okazuje się bowiem, jak przekonuje Markowski, że rzecz cała nie polega na przeciwstawieniu sobie rzeczywistości i tekstu, a „dwóch postaw egzystencjalnych: akceptacji i nieakceptacji życia"23.

Pełne samo-rozumienie likwiduje czas, a więc i przyszłość. Pełne zrozumienie unieważnia nadzieję, która przesuwa, odkłada pojednanie znaku i rzeczy na przyszłość, która jest przyszłością absolutną. Z kolei niezrozumienie - odwrotnie - przyszłość otwiera, a tym samym otwiera to, co w przyszłości może się zdarzyć, a na co nie ma ani nazwy, ani wyobrażenia. To otwarcie właśnie, niemożliwe bez niezrozumienia, nieporozumienia, nie-identyczności, nazywam akceptacją życia. [...] Zamknięcie takiej przestrzeni możliwości, która podważa egologiczną pewność podmiotu, ma swoją nazwę. To śmierć ${ }^{24}$.

${ }^{21}$ Odnoszę się tu oczywiście do określenia zaproponowanego przez Wilhelma Dilthey’a (zob. np. W. Dilthey, Określenie nauk o duchu, tłum. K. Krzemieniowa, [w:] Z. Kuderowicz, Dilthey, Warszawa 1987), ale też do apelu Markowskiego o ponowne "doduchowienie" nauk humanistycznych (zob. M.P. Markowski, Polityka wrażliwości. Wprowadzenie do humanistyki, Kraków [cop. 2013], rozdział Duch i dyskurs).

${ }_{22}$ M.P. Markowski, Humanistyka po dekonstrukcji, [w:] French theory w Polsce, red. E. Domańska, M. Loba, Poznań 2010, s. 51.

23 Ibidem.

${ }^{24}$ Ibidem, s. 52. 
Stając po stronie interpretacji (w liczbie mnogiej), nauki humanistyczne - by podsumować tę część rozważań Markowskiego - stają po stronie życia; śmierć to niemożliwość interpretacji. Nie odnosząc się wcale do myśli Łotmana, Markowski niejako powiela jego uwagi: „[...] interpretacja - pisze - jest sposobem istnienia samego tekstu [...], bez interpretacji tekst zamyka się w pustej formule $\mathrm{A}=\mathrm{A}$, co oznacza, że bez możliwości nieporozumienia, która jest początkiem interpretacji, teksty ani nie mogą istnieć, ani nie mogą być czytane. Teksty nie mogą prze-żyć, nie mogą być dziedziczone, nie mogą być przekładane [...]"25. A zatem to wielość interpretacji i będąca jej warunkiem wielogłosowość ożywiają tekst: każde jego użycie, każda próba zrozumienia aktualizuje go, co jest zbieżne z myślą Łotmana, czy dotyczącą tekstu sensu largo, czy na przykład symbolu (zob. Żywotność kanonu..., s. 92-98). Symbol - jak za Łotmanem pisze Małgorzata Jankowska - „potrafi [...] wchodzić w nowe otoczenie tekstowe i tworzyć w nim związki z innymi znakami czy komunikatami, zachowując przy tym semiotyczno-strukturalną autonomię" (s. 93). Jest to jedna z kilku konstytutywnych cech symbolu wyróżnionych przez Łotmana i omówionych przez autorkę Żywotności kanonu, a wspominam ją dlatego, że koresponduje znakomicie z rozpoznaniami Markowskiego, który pisze, że „nie można ostatecznie zamknąć kontekstu jakiejkolwiek wypowiedzi”, co wskazuje na „nienasycalność kontekstu”, która „oznacza, że żaden tekst nie może liczyć na to, że nie zostanie przeniesiony w inny kontekst niż ten, w którym powstał”, oraz zauważa, że „kontekstualność tekstu to jego historyczność: tekst można przenosić w inny kontekst tylko dlatego, że można go przepisać, powtórzyć, przełożyć, przemieścić, to zaś stanowi o jego zrozumiałości"26. Mamy w przywołanych tu explicite fragmentach kategorię kontekstu, przekładu i historyczności - i wszystkie one pozostają w ścisłym dialogu zarówno z rozpoznaniami Łotmana, jak i tymi wyłożonymi w Żywotności kanonu. Najważniejsze jednak, z perspektywy tego szkicu, jest życie: „jeżeli ta nieuchronna nienasycalność kontekstu - kontynuuje Markowski - należy do

25 Ibidem, s. 58 (podkr. K.M.). Dodajmy, że przywołana tu formuła A=A jest zbieżna z koncepcją translacji tekstów wyłożoną przez Łotmana w Uniwersum umystu i omówioną w Żywotności kanonu (zob. s. 72-73).

26 M.P. Markowski, op. cit., s. 60-61. 
logiki samego życia, to nic i nikt nie może jej zmienić" 27 . Podsumowując, powiedzieć można najkrócej: śmierć to doskonała (a więc i zamknięta, ukończona) tożsamość, życie to interpretacja.

$$
\star * *
$$

Suma kontekstów, w których dany tekst nabiera sensu i które w określony sposób są w nim inkorporowane, może być nazwana pamięcią tekstu. Ta stwarzana przez tekst przestrzeń semantyczna wstępuje w określone relacje z pamięcią kulturową (tradycją), spetryfikowaną w świadomości audytorium. W rezultacie tekst znów zyskuje życie semiotyczne ${ }^{28}$.

Te słowa Łotmana, przywołane przez Małgorzatę Jankowską w kontekście (sic!) życia (sic!) apokryfów, oddają w pewnym stopniu motywy, dla których w niniejszej glosie oddałam głos autorom niereprezentującym semiotycznego nachylenia w swoich badaniach, a jednak proponujących podobne rozstrzygnięcia. „Życie semiotyczne” (też: „życie semantyczne” - zob. s. 79) rozumiane tu być może właśnie również jako życie podtrzymywane przez użycie - interpretację, czyniony wysiłek rozumienia. „Cyrkulacja różnego kształtu elementów semiotycznych odbywa się nieustannie, dlatego kultura rozumiana jako semiosfera jest konstruktem bardzo dynamicznym" (s. 72) czytamy w Żywotności kanonu. Ta dynamika jest niezwykle charakterystyczna dla wspominanego już „późnego” Łotmana i naznacza całą refleksję prezentowaną w monografii. Dynamika bowiem plasuje się po stronie życia i żywotności właśnie, (re)witalizacji i umożliwiającej ją (re)interpretacji. Dla autorki figura muzeum jest w tym świetle podwójnie istotna: $z$ jednej strony stanowi jeden $\mathrm{z}$ wariantów aktywnych i biernych mechanizmów pamiętania i zapominania (s. 124), co pozwala uporządkować kwestie kanonu i archiwum w odniesieniu do apokryfów, ale także metaforycznie: jak się przekonaliśmy, Łotman z tej metafory chętnie korzysta („muzealny rarytas”). Jankowska pisze: uobecniane niegdyś przekazy mogą współcześnie "stanowić wyłącznie zakurzony eksponat w muzeum pamięci kulturowej” (s. 146). Posługując się niezwykle nęcącymi określeniami tekstów - „w użyciu” i „przechowywanymi w archiwum”; „będących w repozytorium tekstów

27 Ibidem, s. 61 (podkr. K.M.).

28 J. Łotman, Uniwersum umysłu..., op. cit., s. 77-78; cytowane w: M. Jankowska, op. cit., s. 74 (podkr. M.J.). 
gotowych do przypomnienia” $\mathrm{i}$ „w kulturowym biurze rzeczy znalezionych” (s.130) - zdaje się wpisywać w Bachtinowskie rozumienie kultury jako puli sensów, będących w mniej lub bardziej potencjalnej dyspozycji, czekających na swoje aktualizacje, a więc i powrót do (semiotycznego) życia.

Oddanie głosu autorom, którzy obierają co prawda różne punkty widzenia, acz ich spojrzenia się krzyżują, miało uczynić tę glosę w pewnym stopniu polifoniczną. Przy całej bowiem świadomości odmienności przedstawionych tu teoretycznych punktów wyjścia trudno oprzeć się wrażeniu, że autorzy ci nie mówią tylko „obok”, a właśnie „do” czy „względem” siebie. To raz. Dwa nie zamierzałam wykazywać tu, że myśl Łotmana jest zbieżna „Z wieloma innymi”, lecz zaproponować pewien, siłą rzeczy skromny, „pejzaż wokalny” skupiony wokół kategorii życia, a co za tym idzie: ożywiania i żywotności. Sprowokował mnie do tego oczywiście tytuł książki, na marginesie której czynię te refleksje, wskazujący przecież, że i dla autorki kategoria ta nie jest bez znaczenia. Żywotność kanonu jest też przy tym znakomitą próbą ożywienia samej dyscypliny. Semiotyka kultury okazuje się doskonałym narzędziem i sposobem reflektowania nad rozmaitymi fenomenami kultury, w tym współczesnej apokryficzności, która wszak jest przedmiotem omawianej tu książki. Przypomnijmy cytat, od którego rozpoczęłam swoją refleksję - zdaje się on dla niej dobrą klamrą: „Semiosfera jest »niedomknięta" i jako taka nie może być w pełni oddana w "zamykającym ją" oglądzie" (s. 174). Podobnie rzecz ma się i z samą semiotyką.

\section{Bibliografia}

Wilhelm Dilthey, Określenie nauk o duchu, tłum. K. Krzemieniowa, [w:] Z. Kuderowicz, Dilthey, Wiedza Powszechna, Warszawa 1987.

Paweł Dybel, Oblicza hermeneutyki, TAiWPN Universitas, Kraków [cop. 2012]. Małgorzata Jankowska, Żywotność kanonu. Semiotyka współczesnej apokryficzności,

Wydawnictwo Nauk Humanistycznych i Społecznych UAM - Wydawnictwo Fundacji Humaniora, Poznań 2019.

Jurij Łotman, O semiosferze, [w:] idem, Kultura, historia, literatura, tłum., wyb. i wstęp B. Żyłko, Wydawnictwo UG, Gdańsk 2017.

Jurij Łotman, Uniwersum umysłu. Semiotyczna teoria kultury, tłum. i wstęp B. Żyłko, Wydawnictwo UG, Gdańsk 2008.

Katarzyna Machtyl, Znaki w ciagłym ruchu. Od optyki podmiotu po perspektywę kulturowa, [w:] Kultury w ruchu: migracje, transfery, epistemologie, red. R. Koschany, M. Michałowska, J. Ostrowska, A. Skórzyńska, 
Wydawnictwo Nauk Społecznych i Humanistycznych UAM - Wydawnictwo Fundacji Humaniora, Poznań 2019.

Michał Paweł Markowski, Humanistyka po dekonstrukcji, [w:] French theory w Polsce, red. E. Domańska, M. Loba, Wydawnictwo Poznańskie, Poznań 2010.

Michał Paweł Markowski, Polityka wrażliwości. Wprowadzenie do humanistyki, TAiWPN Universitas, Kraków [cop. 2013].

Gianni Vattimo, Społeczeństwo przejrzyste, tłum. M. Kamińska, WN DSWE TWP, Wrocław [cop. 2006].

Lech Witkowski, Uniwersalizm pogranicza. O semiotyce kultury Michaiła Bachtina w kontekście edukacji, Wydawnictwo Adam Marszałek, Toruń 2000.

\section{Reviving the Power of the Semiotic View. Thinking Out Loud on the Vitality of (and) the Text}

The gloss is inspired by the Małgorzata Jankowska's monography Vitality of the Canon. Semiotics of Modern Apocrypha and aims at presenting the complex relations between life and text - understood not only metaphorically, but also literally. Starting with the Yuri Lotman's expression 'the life of the text' the author focuses on the one of the basic features of the semiosphere, i.e. dynamics and remaining unfinished. Referring to the so-called late Lotman, the author discusses such issues as explosion, unpredictability and motion in the relation to the text. The next part of the paper contains certain remarks on the convergences of Lotmanian and Mikhail Bakhtin's view on the cultural dynamics and vitality of the text. The issue of the life of the text in the view of hermeneutics is being discussed in the next part of the article. The author refers to Gianni Vattimo's concept of the transparency and 'opaqueness' as its opposite and juxtaposes it with the hermeneutic notion of the understanding which should not be fully performed. Apparently the lack of transparency and being not fully understood is what provides the desirable dynamics of text and culture. As Lotman writes, the text which is fully understood can only be displayed in a museum - it does not have a semiotic life any more. To interpret means to live - a text requires multiple interpretations and contexts to be alive.

Keywords: semiotics, text, life, vitality, interpretation 